Akan, M., \& Konovalova, N. (2021). Optimal Incentives for Economic Growth in Central European Countries: A Micro Approach. Copernican Journal of Finance \& Accounting, 10(3), 9-31. http:// dx.doi.org/10.12775/CJFA.2021.009

\author{
Mustafa Akan ${ }^{*}$ \\ Haliç University \\ Natalia Konovalova** \\ RISEBA University of Applied Sciences
}

\title{
OPTIMAL INCENTIVES FOR ECONOMIC GROWTH IN CENTRAL EUROPEAN COUNTRIES: \\ A MICRO APPROACH
}

Keywords: optimal control theory, incentives for economic growth, fluctuating demand.

J E L Classification: D90, F43, F63, C61.

Abstract: Financial crisis of 2008 and the ongoing pandemic are continuing to have a negative impact on the economies of all countries even tough interest rates have been decreased significantly. This paper attempted to view the problem from a micro point of view to suggest more effective incentives for growth. The specific objective of the study is to determine and examine the effects of these incentives on economic growth in Central European countries.

Date of submission: April 15, 2021; date of acceptance: June 10, 2021.

* Contact information: mustafaakan@halic.edu.tr, Halic University Sutluce Mh. Imrahor Sk. No: 8234445 Beyoglu/Istanbul, Turkey, phone: +905333119405; ORCID ID: https://orcid.org/0000-0002-2900-4932.

** Contact information: natalija.konovalova@riseba.lv, RISEBA University of Applied Sciences, Meza street 3, Riga, Latvia, phone: +37129215208; ORCID ID: https://orcid. org/0000-0003-4072-4479. 
An optimal control theoretic model was employed as a method of analysis with data from countries in question. Results showed, generally, that incentives such as interest rates, investments in production technologies, labor productivity, and the cost of inventory were important factors to induce growth with different impact in each country. Results showed that changes in interest rates will not cause significant economic growth in Poland, Hungary, and the Czech Republic where interest rates are already low. However, countries such as Croatia and Romania where interest rates are relatively high, reducing interest rates may lead to economic growth. The investment in production technologies will have a significant impact on economic growth in Bulgaria, Hungary and Croatia. For the Czech Republic, Slovenia and Poland, which are already quite advanced in the field of production technology, the impact of this factor on economic growth will be less significant. Incentives to increase labor productivity in Hungary, Bulgaria, Estonia, Latvia, and Lithuania will have significant impact on economic growth as productivity in these countries is relatively low. Incentives regarding holding costs will be effective on sectoral basis.

\section{IIIIRODUCTION}

Governments have taken actions to stabilize the financial sector by principally increasing money supply and other measures such as taking over some of the financial institutions affected by the crisis. Growth rates in advanced countries are low and are forecasted to remain low for several more years. The trade war between the USA and China will surely have a negative impact on the growth rates. Outbreak of a virus in China will probably have a negative impact on growth. AFP (2020) estimates that the impact could be 0.1-0.2 \%. Giles, Arnold and Greely (2020) have reported that OECD lowered its growth estimates for the World from $2.9 \%$ to $2.4 \%$ for 2020 . All major economies of the World have taken monetary measures to minimize the impact of financial crisis on the real sector. These policies worked well in most countries to contain the financial crisis but not so well to induce growth which is evident from the growth rates in 2009 and thereafter. The interest rates in major economies of the World are already low. They are zero in Eurozone, negative in Japan. Inflation rates in almost all major economies are low implying that the consumers are not borrowing for consumption even though the interest rates are generally very low. These two facts are good indications of the end of effectiveness of monetary (easy money, low interest rate) policies. 
A brief review of literature shows such measures have either been ineffective, insignificant, or even negative. Carlianne (2014) found that governments aiding private enterprises has significant negative mid-term effect on employment and growth. Osario and Florida (2017) showed that business incentives have different impacts in different areas and are usually ineffective, costly, and wasteful. Peters and Fisher (2004) have concluded that incentives are costly and do not encourage investment. Kosonen (2012), in a study on Finnish firms, have found that decreasing taxes would increase the production but the tax elasticity of production is only -0.17. Petrin (2018) concluded that incentives for R/D and innovation might have positive impact but not always. A report by DPME/DSBO (2018) could not make a conclusion on the impact of government incentives on business. Conroy (2019), in her master thesis, concluded that there is a positive impact of incentives on attracting investment to a state but it depends on the type of incentives. Prillaman and Meier (2014) concluded that state tax cuts have little to no positive on the growth of the state, job creation, personal income, poverty rates, and formation of new businesses. A report by Christian, Karlin, Schaff and Tucker-Roy (2019) found a positive relationship between incentive spending and jobs created only if specific objectives are set, measurable goals are defined, and investment is made in staff, systems, and budget. Bundrick (2016) showed that incentives have costs and they create market distortions. In a study for center for American Progress, Schwartz (2018) concluded that subsidies fail to meet promised results with no net benefit to the social welfare. A report by the PEW Charitable Trusts (2019) states that incentives help create an unstable economy. Mitschell (2019) concluded that incentives lead to a slower growth. A review report by World Bank (1999) has shown that, when all other factors such as infrastructure, transport costs, and political and economic stability, are approximately equal, the taxes may have significant impact on investors' location choices. The report also concluded that this effect depends on the tax instrument. Miller and Atkinson (2014) concluded that investment in Information and Communication Technology (ICT) brings about a transformative change to organizations resulting in increased productivity. Buss (2001), in his review of literature report on state tax incentives, summarized his report by stating that tax studies offer little guidance as tools of economic development. Klemm and Parys (2012) found the evidence that taxes were effective attracting Foreign Direct Investment into Latin America and Caribbean but not effective on increasing gross private fixed capital. Crespi, Guiliodori, Guiliodori and Rodriguez (2016) studied the impacts of 
promoting firm level investments in R/D in Argentina and found that elasticity of such investments is greater than 1 and effects vary on the sector and the size of the firm. The effects vary depending on the type of investment considered. Zee, Stotsky and Ley (2002) concluded that tax incentives should be directed towards rectification of market failures and that cost effectiveness of such incentives are inconclusive. In their recent paper, Tadesse and Melaku (2019) has shown that monetary policies were less effective than fiscal policies in the long run and ineffective in the short run in Ethiopia.

The review of literature above on the impact of government incentives are, by no means, exhaustive, shows that they are largely ineffective, in some cases detrimental to proper functioning of the economy. In any case, there is not a consensus on the effectiveness of such measures. Some studies show, properly structured, incentives may have positive impacts.

One purpose of this paper is to contribute to this search for proper incentives by studying the dynamic behavior of real sector companies from a micro point of view to determine the conditions under which they will produce more under various demand expectations. Another purpose of the paper is to analyze the factors that affect the production behavior of the firms and suggest more realistic macro policies to increase growth other than reduction of borrowing costs (interest rates). It is not the purpose of this paper to compare the effectiveness of micro and macro policies or to search for incentives to increase consumption.

In the next section, a brief review on incentives for firms will be provided. In Section III. a general dynamic model of a real sector company (nonservice) operating in a competitive environment facing oscillating demand and different interest rate expectations will be developed using an optimal control theoretic model will be presented. The examples of solutions under different assumptions will be solved in the section IV to observe the effects of changes in some parameters such as interest rates, costs, and changes in demand structure. Results, conclusions, and policy implications of the results will follow in subsequent sections. Some further research will be suggested in the last section. 


\section{RESEARCH METHODOLOGY}

The general scheduling production planning problem of a firm operating in a perfectly competitive market (where price is constant) can be modelled as a cost minimization (sum of cost of production and inventory holding cost) where:

$u(t)$ : the level of production at time $t$,

$c(u)$ : strictly convex cost function

$h$ : unit holding cost, a constant. These costs include many cost items such as rent, cost of relevant equipment necessary to keep the products in the inventory, and insurance premiums.

$r(t)$ : level of demand that is an exogenously determined function of time

$l(t)$ : the level of inventory at time $t$, which increases by production $(u(t)$ and decreases by sales $r(t)$. Therefore, the model, is

$$
\max _{u(t)} \int_{0}^{T}[c(u(t))+h I(t)] d t
$$

Subject to the constraints:

$$
\begin{aligned}
& I^{\prime}=u(t)-r(t) \\
& I(0)=I_{0} \text { given }
\end{aligned}
$$

and the non-negativity constraints.

$$
u(t) \geq 0, I(t) \geq 0
$$

Cost minimization is considered since the price is assumed to be constant and the demand, $r(t)$, is an exogenous time dependent function making the revenues an exogenous function also thus irrelevant in decision making.

The last constraint is a state variable inequality constraint which has been studied by many authors including Bryson and Ho (1975), Bryson, Denham and Dreyfus (1963), Jacobson and Lele (1969), Jacobson, Lele and Speyer (1971), McIntyre and Paiewonsky (1967), and Sprzeuzkouski (1967). Taylor (1972) studied the problem stated above with no interest rate consideration and has found that; 
$c^{\prime \prime}(r(t)) r^{\prime}(t) \leq h$ is the condition which has to hold for the firm to keep $I(t)=0$ which implies that the firm will produce just to meet the demand.

The firm will start producing not only to meet the demand but also to build up inventories when the change in demand is such that the above inequality will be violated.

In this paper, we will study the same problem introducing present value factor and fluctuating time dependent demand function.

Then, the problem becomes:

$$
\operatorname{Min} \int_{0}^{T} e^{-i(t)}[c(u(t)+h I(t)] d t
$$

Subject to the constraints:

$$
\begin{aligned}
& I^{\prime}=u(t)-r(t) \\
& I(0)=I_{0} \text { a given number. } \\
& u(t) \geq 0 \\
& I(t) \geq 0
\end{aligned}
$$

With the assumptions that the demand $(r(t))$ is a simple sinusoidal function and the interest rate $i(t)$ is time dependent, i.e.:

$$
r(t)=A+B \sin (2 k \pi t) \text { with no growth, and, }
$$

$i(t)=\int_{0}^{t} f(s) d s$ implying that $i(t)=f t$ if $f$ is constant. Notice also that $i^{\prime}(t)=f(t)$ where $\mathrm{f}(\mathrm{t})$ denotes time dependent interest rate. For ease of analysis we will assume $f(t)$ to be constant. The letter k denotes the periodicity of the sinusoidal demand function over the planning period. The only reason for the use sinusoidal demand curve is that it represents cyclicality (a measure of risk) and that it is easier to work with it.

The appropriate Lagrangian for this problem is:

$$
H=e^{-i(t)}[c(u(t))+h I(t)]+\rho(t)(u(t)-r(t))+\mu(t)(r(t)-u(t))
$$


Then the necessary conditions are:

$$
\begin{aligned}
& e^{-i(t)} c^{\prime}(t)+\rho(t)-\mu(t)=0 \\
& \rho^{\prime}(t)=-e^{-i(t)} h \\
& I^{\prime}(t)=u(t)-r(t)
\end{aligned}
$$

Necessary conditions are also sufficient since the Hamiltonian is convex in both the control $(u)$ and state $(l)$ variables.

The planning horizon $(T)$ will be assumed one.

On a constraint arc on which $l(t)=0$ for a certain period in $[0,1]$ i.e. $0<t_{1} \leq t \leq t_{2}<1$ we have; $I^{\prime}=0=u(t)-r(t)$ implying that over this period a firm will produce just enough to meet the demand, which is assumed to be nonzero during the planning horizon.

Then using $u(t)=r(t)$, equation (1), and the conditions (the necessary condition to keep $I(t)=0$ optimal) developed by Pontryagin, Boltyanskii, Gamkrelidze and Mishechenko (1962), Hestenes (1966), Kamien and Schwartz (2012) among many others, we have;

$$
\begin{aligned}
& \mu^{\prime}(t) \leq 0 \text { for } t_{1} \leq t \leq t_{2} \text { implies: } \\
& c^{\prime \prime}(r(t)) r^{\prime}(t) \leq h+f(t) c^{\prime}(r(t))
\end{aligned}
$$

where $f(t)=i^{\prime}(t)$ denotes the interest rate.

As long as the condition specified by this inequality is satisfied it will be optimal to keep $I(t)=0$ implying $u(t)=r(t)$. This means that during the intervals where this inequality is satisfied the firm will produce just enough to satisfy the demand. So, the condition above will synthesize the periods where $I^{\prime}(t)=0$ or $u(t)=r(t)$ and the periods where $I(t)>0$.

Notice that for the condition above (equation 4 ) to be kept satisfied depends on $h$ (inventory holding cost), $f(t)$ the interest rates, $c^{\prime}(t)$, the marginal cost of production, and $c^{\prime \prime}(t)$ change in the marginal cost.

Following conclusions can be made even without specific forms of $c(t), f(t)$, $r(t)$ and $i(t)$ on the basis of equation (4): 
1. The firm will keep $l(t)=0$ as long as demand is falling or constant i.e. $r^{\prime}(t) \leq 0$ implying that the firm will choose to produce just enough to meet the demand if demand is falling since both $h$ and $c^{\prime}$ are positive.

2. The firm will keep $l(t)=0$ even if demand is increasing $\left(r^{\prime}(t) \geq 0\right)$ but the term $h+f(t) c^{\prime}(r(t))$ is large enough to keep inequality (4) satisfied. Decreasing interest rates will not be a remedy in this case if they are already low. Firms where $c^{\prime \prime}(r(t))$ is low (large and already very efficient firms) will have more difficulty to produce to build up inventories. Currently, this seems to be the case in major economies.

3. Higher interest rates and the use of inefficient technologies (large $c^{\prime}(r)$ ) implies high marginal cost) will induce firms to wait longer for inventory build-up even if $r^{\prime}(t)$ is positive.

4. The level of technology used will not affect the behavior of the firms if the interest rates are very low as they are now in many developed nations since the term $f(t) c^{\prime}(t)$ in equation will be low even if $c^{\prime}(t)$ is high (a firm technologically inefficient.). In countries with high interest rates, the importance of efficient technologies is evident because both terms $\left(f(t)\right.$ and $c^{\prime}(t)$ are) large.

5. The cyclicality of demand and the time dependency of interest rates can affect the producers. Producers, facing cyclical demand with very high periodicity will have extreme difficulty in planning and hence may not produce for inventory buildup at all. Cyclicality in the following examples is denoted by the parameter $\mathrm{k}$. The value of $\mathrm{k}$ will be assumed to be 1 in all cases for simplicity. For higher values of $k$, trigonometric functions will complete 360-degree cycle twice in the planning horizon. The results will not change except the firms will stop and start two times in the planning period indicating more instability of demand.

6. Size of the firms, expressed as a constant in the total production cost $(c(r))$, is irrelevant in production decisions since it will not appear in equation (4).

In the next section, the impact of holding cost, technology, and interest rates on the production behavior of firms is analyzed with different assumptions on interest rates and a specific form of cost function (a cubic function of level of production). Graphs are produced to visualize the impact of assumptions about interest rates, parameters of demand function, and holding cost. 


\section{RESEARCH PROCESS}

The specific cost function, in this example, will be assumed to have the more realistic form of:

$$
c(r(t))=a r^{3}+b r^{2}+c r+d \text { and }
$$

$r(t)=A+B \sin 2 k \pi t$ as defined previously where $k$ represents the periodicity of the demand function.

In the examples below, we will assume that $a=0.5, B=1, A=4, h=5 \pi$, $b=-1, c=1$ for simplicity.

Case I: $k=1$ (one cycle of the demand curve in the planning horizon of one and interest rate $f(t)=0$.)

Then the inequality (4) becomes:

$$
(0.5 * 3(4+\sin 2 \pi t)-1) \cos 2 \pi t \leq 2.5
$$

Both sides of inequality in (5) is presented in the graph below produced using arbitrary numbers for relevant variables (figure 1).

This graph (figure 1) implies (notice the tip of arrows in the graph shows the times production is stopped and started) that the firm will stop producing for inventories just before the demand reaches its maximum and starts just after the demand reaches its minimum (recall that the sinusoidal demand reaches its maximum at $t=0.25$ and its minimum at $t=0.75$ ). These points are indicated by arrows in all graphs (the tip of the arrow shows the point at which the left, 0.18 , and right, 0.86 ) hand side of equation 4 becomes equal). Therefore, it is only possible for firms to stop producing later and start producing earlier is to decrease the holding costs $(h)$ as defined above. 
Figure 1. Graphs of Left $(f(t))$ and Right $(g(x))$ hand sides of Inequality (5) and Demand Function $(h(x)=r(t))$

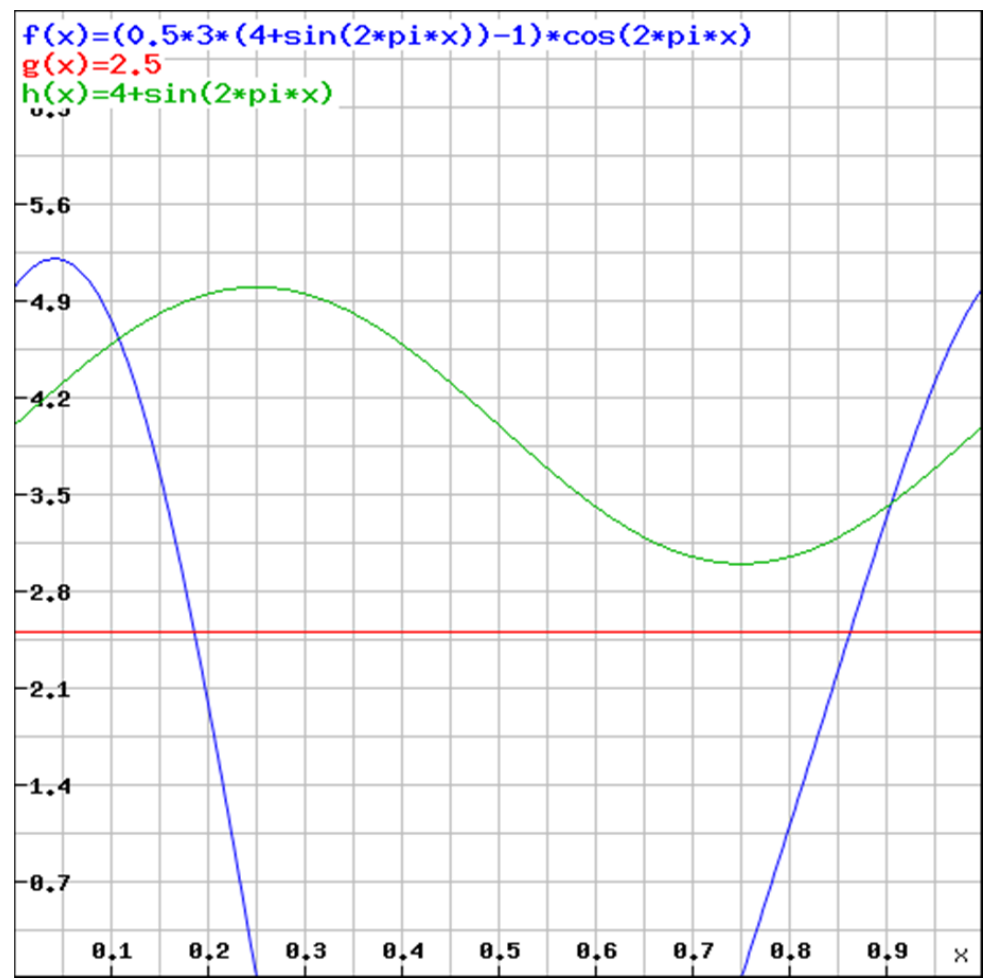

S o u r c e : constructed by authors.

Case II: $k=1$ and interest rate $f(t)=0$ and a new technology I introduced. The impact of new technology will be analyzed in three cases:

1. Fixed costs (the term $d$ in the cost function) is reduced.

There will be no impact on production decision since the fixed costs are already shown to have on impact on the inequality (5).

2. Only the constant term $(c)$ in the marginal cost, $c^{\prime}=3 a r^{2}+2 b r+c$ is reduced.

The left-hand side of inequality (5) will not change since $c$ " $(r)$ does not depend on the constant term $c$ in the production cost function. The right-hand side will be lower since $c$ is lower. Therefore, the decision of the firm will depend on how much the new technology reduces $c$. The firm will start to produce sooner if the reduction in $\mathrm{c}$ is large enough to violate the inequality. 
3. Marginal cost function, $c^{\prime}(r)$, is reduced as a whole.

We will consider this last case assuming that the new technology reduces the marginal cost by $20 \%$. This implies that the left-hand side of inequality (5) will be multiplies by 0,8 .

Then the inequality (4) becomes:

$$
(0.5 * 3(4+\sin 2 \pi t)-1) \cos 2 \pi t * 0.8 \leq 2.5
$$

Therefore, for the same values for the constants, the graphs of both sides of inequality above and the sales are presented below (figure 2).

Inequality (6) implies the same type of results as in the previous case. However, it is evident from the graphs that in the second case the firm will stop producing sooner and start producing later than in the first case. This is an important result because it indicates that introduction of new technologies which reduces the marginal costs will induce firms to stop production sooner.

Case III: $k=1$ and interest rate $f(t)=0.2$

The inequality (4) becomes:

$$
\begin{aligned}
& (0.5 * 3(4+\sin 2 \pi t)-1) \cos 2 \pi t \\
& \quad \leq 2.5+0.2(0.5 * 3 *(4+\sin 2 \pi x))^{2}-2 *(4+\sin (2 \pi x)+1) / 2 \pi
\end{aligned}
$$

The graphs of the function on both sides of this inequality above are shown in graph III below (figure 3).

Figure 3 shows that introduction of interest rates causes the firms to stop production sooner but not very significantly, from $t=0.18$ in graph I to about 0.16 in graph III. This implies that the firms will start to produce at about the same time as when interest rate was zero (Figure 1). This, in turn, implies that firms will stop producing later when interest rates are lowered. However, they will not start producing sooner.

Case IV: $k=1$ and interest rate $f(t)=0.1$, a $50 \%$ decrease in interest rate. In this the inequality (5) becomes:

$$
\begin{aligned}
(0.5 * 3(4+ & \sin (2 \pi t)-1) * \cos 2 \pi t \\
& \leq 2.5+0.10 *\left(0.5 * 3 *(4+\sin (2 \pi x))^{2}-2\right. \\
& *(4+\sin (2 \pi x)+1) / 2 \pi
\end{aligned}
$$


The graphs of the functions on both sides of this inequality are shown in figure 4 below.

Case V: $k=1, f=50 \%$.

Reducing the interest rate from 0.10 to 0.05 , we get figure 5 .

Figure 2. Graphs of Left $(f(x)$ and Right $(g(x))$ Sides of Inequality (6) and Demand Function $(h(x))$

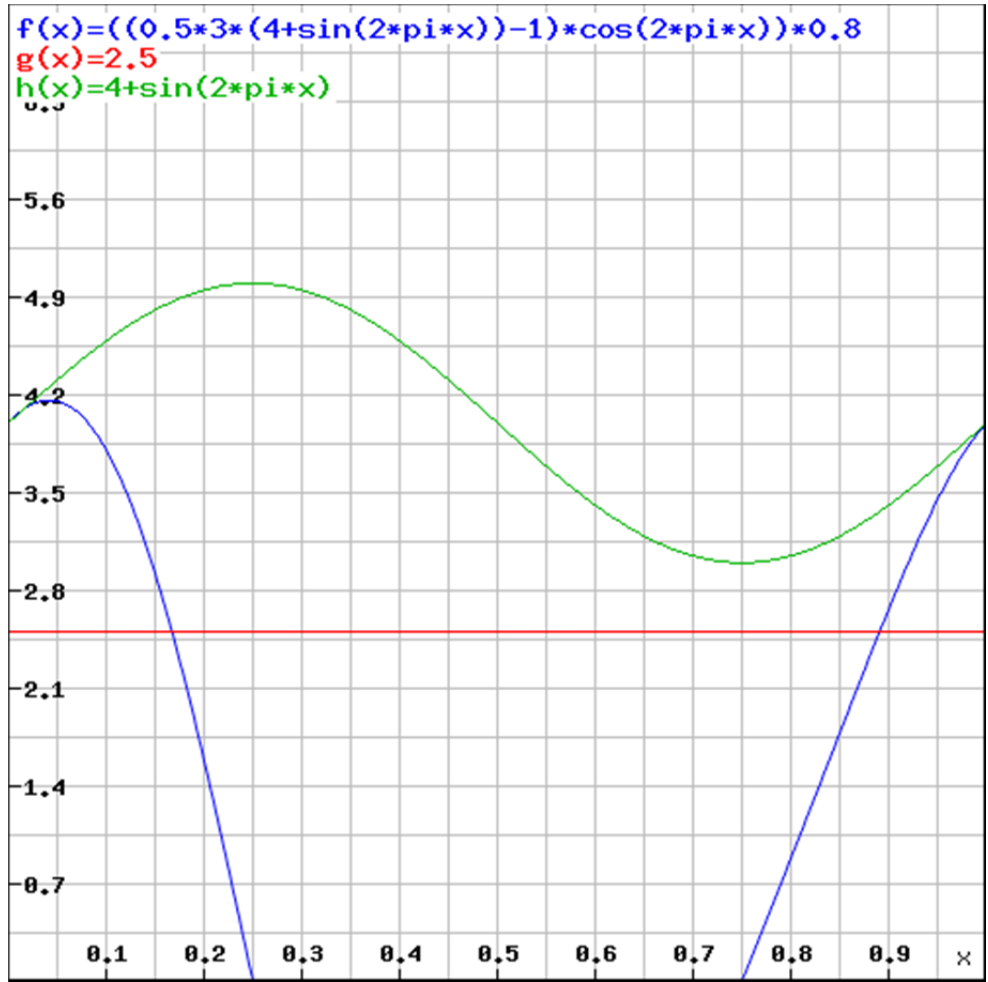

S o u r c e : constructed by authors. 
OPtIMAL INCENTIVES FOR ECONOMIC GROWTH...

Figure 3. Graphs of Left $(f(x)$ and Right $(g(x))$ Sides of Inequality (7) and Demand Function $(h(x))$

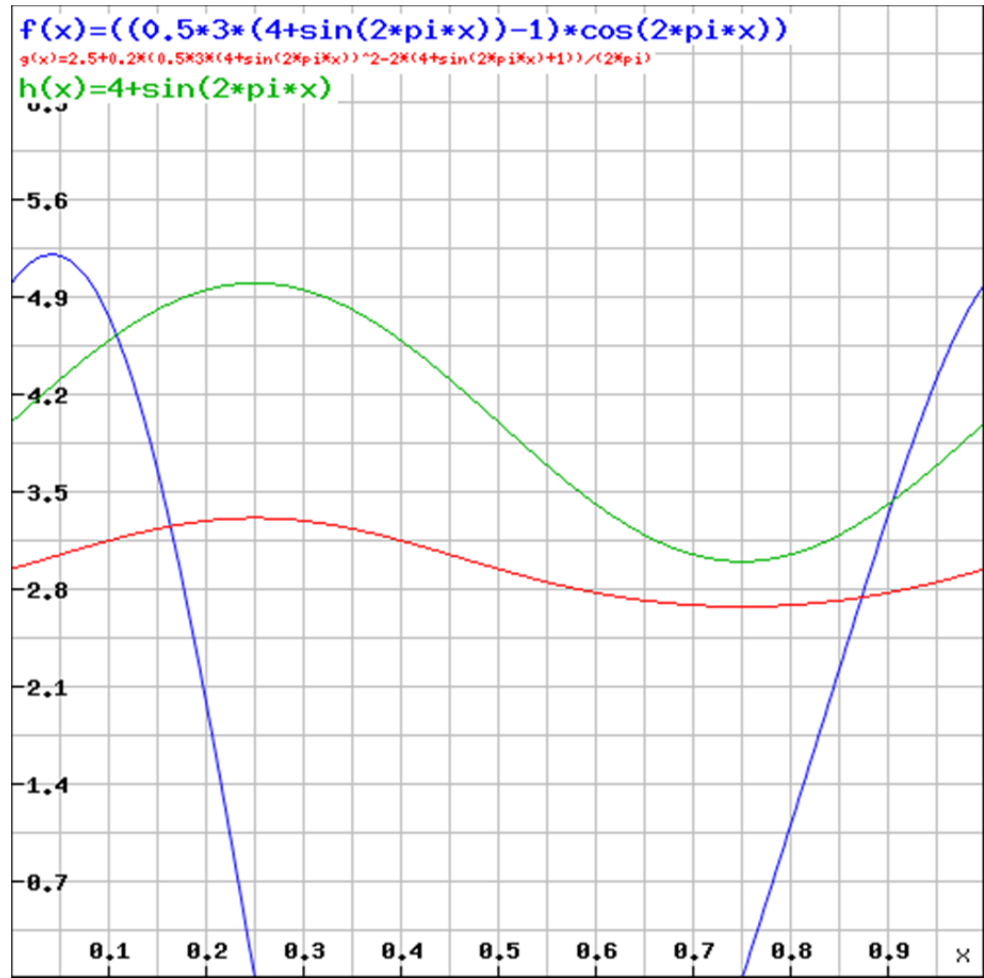

S o u r c e : constructed by authors. 
Figure 4. Graphs of Left $(f(x)$ and Right $(g(x))$ Sides of Inequality (8) and Demand Function $(h(x))$

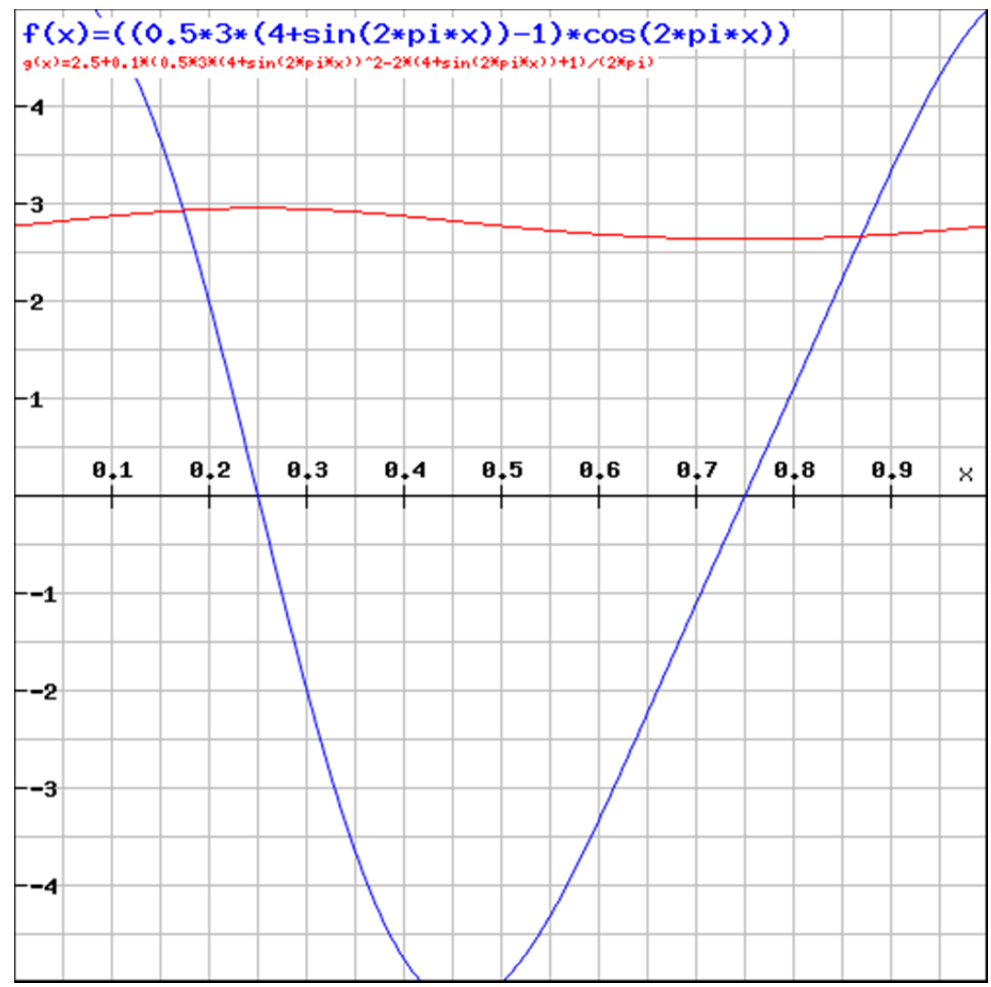

S o u r c e : constructed by authors.

Notice in this case that the firms stop and starts production at about the same time as in the case when interest rate is $=20 \%$ (previous case) implying that reduced interest rates do not affect production significantly. 
Figure 5. Graphs of Left $(f(x)$ and Right $(g(x))$ Sides of Inequality (8) and Demand Function $(h(x))$ with $f(t)=5 \%$

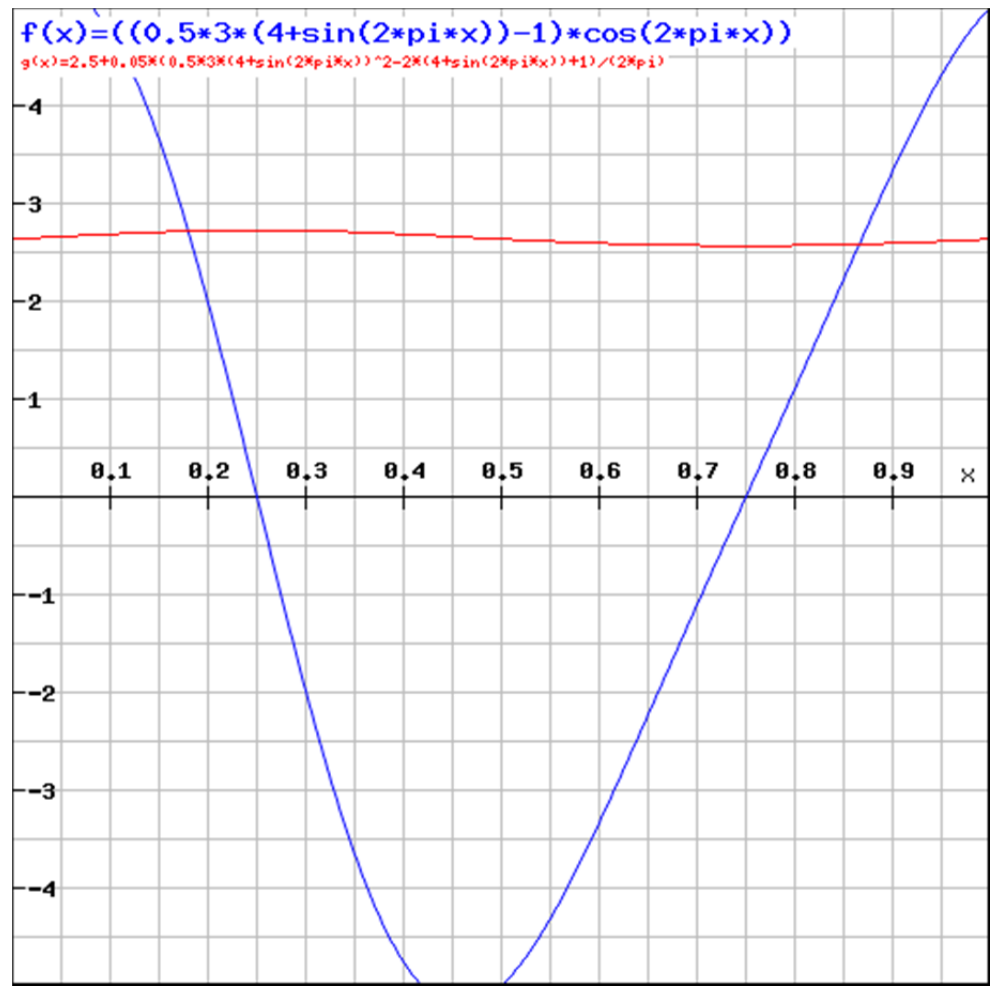

S o u r c e : constructed by authors.

Notice that the times at which production stopped and restarted are the same as in the case when interest rate was $10 \%$. This is an important result since it helps to explain why low interest rates are no longer effective to induce growth. 


\section{RESEARCH RESULTS AND CONCLUSIONS}

\section{General Results and Conclusions:}

Based on the study of cases I-V and the graphs associated with these cases, following results and their policy implications can be summarized as:

1. High holding costs affect the production decisions negatively.

2. The impact of new technologies depends on the efficiencies brought about by the new technology. New technology has no impact on production decision if it reduces the fixed costs only or the fixed part of the marginal cost. The firm will stop producing sooner and start producing later if the new technology reduces the total marginal costs. This is a perplexing result since common sense would dictate otherwise.

3. Changes in interest rates (with the assumed value of the parameters) do not affect production.

4. Cyclicality of demand will affect production plans. Extreme periodicity (cyclicality) of demand may result in firms never producing for inventories. In case of higher cyclicality, both the demand and the cost functions will fluctuate as many times as the cyclicality in a given time horizon (assumed to be 1 here) which will imply that the firm will start and stop production many times which is not a conducive situation for investment.

5. Firm size (as expressed by the constant $d$ in the expression of cost function) has no impact on the production decisions. Hence, no differentiation should be made between small and large firms when incentives to induce firms to produce for inventories are considered.

6. Effects of changes in interest rates are especially ineffective if the interest rate is already small.

7. Tax incentives have no impact on production since equation (4) does not involve any tax parameter.

Therefore:

Incentives for firms to lower their holding costs are an effective method to induce firms to keep production above demand. These may include lower prices for electricity, oil, and gas, lower property insurance rates, and lower insurance premiums for labor to reduce holding costs. Incentives for introducing 
new technologies may be only effective if they are carefully chosen. Incentives to reduce marginal costs will not be effective.

\section{Implications for Central and Eastern European Countries}

The model above was developed for a company operating in a competitive sector. The model was not intended to identify proper incentives for growth in extraordinary times like Covit-19 crisis the whole world is facing or 2008 financial crisis. The model was not intended to address incentives directed to attracting foreign investment either. Tax incentives are not addressed since a firm operating in a perfectly competitive sector tries only to minimize its costs.

Three important factors are relevant in the context of the paper. They are the interest rates, the production technology, and the holding cost of inventories. Thus, the implications for the Central and Eastern European Countries will be analyzed based on these factors.

There are many classifications of Central and Eastern European Countries. Central and Eastern European Countries (CEECs) is an OECD term for the group of countries comprising Albania, Bulgaria, Croatia, the Czech Republic, Hungary, Poland, Romania, the Slovak Republic, Slovenia, and the three Baltic States: Estonia, Latvia and Lithuania (OECD, 2001). According to the National Institute of Statistics and Economic Research of France (Insee, 2020), the Central European countries defined are Bulgaria, Croatia, Estonia, Hungary, Latvia, Lithuania, Poland, Romania, Slovenia, Slovakia, Czech Republic. Authors use both above mentioned classifications and chose the following 11 countries of Central and Eastern Europe according to In see classification for demonstration of implications of economic incentives on growth. The interest rates in these countries are shown in table 1.

Table 1. Interest Rates in Central and Eastern European Countries (\%)

\begin{tabular}{|l|c|c|c|}
\hline \hline \multicolumn{1}{|c|}{ Countries } & Last & Previous & Dates \\
\hline \hline Croatia & 2.50 & 2.50 & May/20 \\
\hline Romania & 1.75 & 1.75 & Jun/20 \\
\hline Hungary & 0.60 & 0.75 & Jul/20 \\
\hline Czech Republic & 0.25 & 0.25 & Jun/20 \\
\hline
\end{tabular}


Table 1. Interest...

\begin{tabular}{|l|c|c|c|}
\hline \hline \multicolumn{1}{|c|}{ Countries } & Last & Previous & Dates \\
\hline \hline Poland & 0.10 & 0.10 & $\mathrm{Jul} / 20$ \\
\hline Bulgaria & 0.00 & 0.00 & $\mathrm{Jul} / 20$ \\
\hline Estonia & 0.00 & 0.00 & $\mathrm{Jul} / 20$ \\
\hline Latvia & 0.00 & 0.00 & $\mathrm{Jul} / 20$ \\
\hline Lithuania & 0.00 & 0.00 & $\mathrm{Jul} / 20$ \\
\hline Slovakia & 0.00 & 0.00 & $\mathrm{Jul} / 20$ \\
\hline Slovenia & 0.00 & 0.00 & $\mathrm{Jul} / 20$ \\
\hline \hline
\end{tabular}

S o u r c e : TRADING ECONOMICS (2020).

Thus, the first implication of the outcome of the results of this paper is that reducing interest rates will not induce growth significantly except perhaps in Croatia and Romania where interest rates are relatively high.

The second factor influencing growth positively was the production technology (production function). However, each firm operating in any economy where free market economy is practiced has a different technology. It is not possible to suggest incentives concerning technology for each firm in an economy. However, it is possible to make a general statement on incentives to invest in better production technologies for a country.

Results of a ranking study by Schwab (2019) on competitiveness index of Central European Countries among 141 countries are shown in the column (1) on table 2. Results of another ranking study by Getzoff (2020) on the Most Technologically Advanced Countries (among 67) are shown on column (2) on the same table. OurWorldInData.org (2021) has produced data on labor productivity in all countires on the basis of Feenstra, Inklaar and Timmer (2015). The data for Central and Eastern European Countires are produced in column 3 of table 2 also.

Table 2 indicates that Estonia, Czech Republic, Slovenia, and Poland are already quite advanced in production technology. Thus, incentives regarding investment in production technologies in these countries will have less impact on growth than they will have in other countries in the region especially in Bulgaria, Hungary, and Croatia. 
Incentives to increase the labor productivity in Hungary, Bulgaria, Estonia, Latvia, and Lithunia will have more impact on growth than in other countries in the region since labor productivity is relatively low in these countries.

Table 2. Competitivity, Advancement, and Labor Productivity in Central and Eastern Europe

\begin{tabular}{|c|c|c|c|}
\hline Countries & $\begin{array}{c}1 \\
\text { (Competitiveness) }\end{array}$ & $\begin{array}{c}2 \\
\text { (Advanced) }\end{array}$ & $\begin{array}{c}3 \\
\text { (Productivity) } \\
\text { (GDP\$/Hour, 2017) }\end{array}$ \\
\hline Croatia & 63 & 39 & 34.25 \\
\hline Romania & 51 & 48 & 33.25 \\
\hline Hungary & 47 & 35 & 25.32 \\
\hline Czech Republic & 32 & 28 & 34.76 \\
\hline Poland & 37 & 34 & 31.06 \\
\hline Bulgaria & 49 & 51 & 23.26 \\
\hline Estonia & 31 & 20 & 28.03 \\
\hline Latvia & 41 & 30 & 28.09 \\
\hline Lithuania & 39 & 27 & 29.46 \\
\hline Slovakia & 42 & 41 & 32.73 \\
\hline Slovenia & 35 & 33 & 35.63 \\
\hline
\end{tabular}

S o u r c e : constructed by authors based on: data TRADING ECONOMICS (2020); OurWorldInData. org (2021).

Skorupinska and Torrent-Sellens (2015) analyses stage of transition to knowledge economy in CEE countries and shows that there is considerable gab between CEE and EU countries in human capital, infrastructure, innovation capacity and quality institutions.

A summary of a study by Radosevic (2017) on Technology in Central and Eastern European Economies is presented below.

Coupling domestic technology efforts with the import of new equipment and management practices could help promote technology upgrading. 
Production capability and engineering, in addition to research, are important antecedents to development and innovation.

Production capability is the most significant driver of productivity growth.

Innovation policy in CEE is based solely on R\&D, imitating best practices in northern Europe, instead of addressing regionally specific challenges.

CEE economies over-prioritize attracting foreign direct investment and do not place enough emphasis on the quality of subsidiary developments.

Radosevic's conclusions, from a macro point of view, support the same conclusions we derived in our micro study from technology point of view.

The third implication of our results was that the inventory holding costs were important in inducing growth. However, it is not possible to make generalizations concerning these costs with regards to a whole region other than the recommendations made in the previous section. Incentives in terms of holding costs should be based on sectors. Companies producing very high value products such as cars, computers, planes should get better incentives since they are more likely to have higher holding costs.

The general conclusions on Central European Countries are:

1. Lowering interest rates will not have an appreciable effect on growth.

2. Incentives regarding improvement of production technology will be effective.

3. Incentives regarding holding costs should be instituted on sectorial basis.

The incentives related to points 1 and above are relatively easy to institute. However, the incentives regarding point 2 will take a longer time to make a significant difference in spurring growth. In the short run, the governments of the region can institute incentives to lower the marginal cost of production for all sectors to reduce the cost of inputs to the production process such as cost of energy (lower taxes on energy, sell energy at a lower price), water, labor (reduce social security premiums paid by the employee), taxes on raw materials.

The analysis above is only for firms competing in a perfect market facing a deterministic time dependent function. A natural extension of this model is to make the demand stochastic in other market forms such as monopolistic or oligopolistic markets. 


\section{REFERENCES}

AFP (2020). Coronavirus could damage global growth in 2020: IMF. Bangkok Post, https://www.bangkokpost.com/world/1859319/coronavirus-could-damage-globalgrowth-in-2020-imf (accessed: 17.02.2020).

Bryson, A., Denham, W., \& Dreyfus, S. (1963). Optimal Programming with Inequality Constraints. AIAA Journal, 1(11), 2544-2550. http://dx.doi.org/10.2514/3.2107.

Bryson, A.E., Jr., \& Ho, Y.-C. (1975). Applied Optimal Control. Washington: Hemisphere Publishing Co.

Bundrick, J. (2016). Tax Incentives and Subsidies: Two Stables of Economic Development. Arkansas Center for Research in Economics, University of Central Arkansas.

Buss, F.T. (2001). The Effect of State Tax Incentives on Economic Growth and Firm Location Decisions: An Overview of the Literature. Economic Development Quarterly, 15(1), 90-105. http://dx.doi.org/10.1177/089124240101500108.

Carlianne, P. (2014). Does Increasing Available Non-Tax Economic Development Incentives Result in More Jobs? National Tax Journal, 67(2), 351-386.

Christian, G., Karlin, M., Schaff, R., \& Tucker-Roy, S. (2019). How State and Local Governments Win at Attracting Companies?. McKinsey and Company, https://www.mckinsey.com/industries/public-sector/our-insights/how-state-and-local-governmentswin-at-attracting-companies.

Conroy, C.M. (2019). Do Economic Incentives Work? Evaluating the Effect of Incentives Designed to Attract Investment on a Stat. Master of Public Policy. Georgetown University. Washington D.C. https://repository.library.georgetown.edu/bitstream/handle/10822/1055104/Conroy_georgetown_0076M_14267.pdf?sequence=1.

Crespi, C., Guiliodori, D., Guiliodori, R., \& Rodriguez, A. (2016). The effectiveness of tax incentives for R\&D in developing countries: The case of Argentina. Research policy: policy, management and economic studies of science, technology and innovation, 45(10), 2023-2035.

DPME/DSBD (2018). Evaluation of Government Business Incentives Report. Pretoria: Department of Planning, Monitoring and Evaluation, https://www.dpme.gov.za/publications/Reports\%20and\%200ther\%20Information\%20Products/Business $\% 20$ Incentives\%20Draft\%20Full\%20Report\%20V7\%2005112018\%20STC.pdf.

Feenstra, R.C., Inklaar, R., \& Timmer, M.P. (2015). The Next Generation of the Penn World Table. American Economic Review, 105(10), 3150-3182. http://dx.doi.org/10.1257/ aer.20130954.

Getzoff, M. (2020). Most technologically Advanced Countries in The World, Global Finance.

Giles, G., Arnold, M., \& Greely, B. (2020). OECD Warns That Coronavirus Could Halve Global Growth. France24 TV, https://www.ft.com/content/1356af8c-5c6c-11ea8033-fa40a0d65a98 (accessed: 3.03.2020).

Hestenes, M.R. (1966). Calculus of Variations and Optimal Control Theory. New York: John Wiley \& Sons.

IMF (2019). World Economic Outlook, https://www.imf.org/external/datamapper/ NGDP_RPCH@WEO/OEMDC/ADVEC/WEOWORLD.9.10.2018-2019. 
Institut national de la statistique et des études économiques (Insee) (2020). https:// www.insee.fr/en/metadonnees/definition/c2055 (accessed 29.07.2020).

Jacobson, D.H., \& Lele, M.M. (1969). A Transformation Technique for Optimality for Control Problems with State Variable Inequality Constraint. IEEE Transactions on Automatic Control, AC-14(5), 457-464.

Jacobson, D.H., Lele, M.M., \& Speyer, J.L. (1971). New Necessary Conditions of Optimal Control Problems with State Variable Inequality Constraints. Journal of Mathematical Analysis and Applications, 35(2), 255-284. http://dx.doi.org/10.1016/0022247X(71)90219-8.

Kamien, M., \& Schwartz, N. (2012). Dynamic Optimization. Amsterdam: Elsevier.

Klemm, A., \& van Parys, S. (2012). Empirical evidence on the effects of tax incentives. International Tax and Public Finance, 19(3), 393-423. http://dx.doi.org/10.1007/ s10797-011-9194-8.

Kosonen, T. (2012). The Impact of Tax Incentives on the Economic Activity of Entrepreneurs. NBER Working Paper, 18442, 1-48. http://dx.doi.org/10.3386/W18442.

McIntyre, J.Mc., \& Paiewonsky, B. (1967). On Optimal Control with Bounded State Variables. In C. Leondes (Ed.). Advances in Control Systems. New York: Academic Press.

Miller, B., \& Atkinson, R.D. (2014). Raising European Productivity Growth Through ICT. Information Technology and Innovation Foundation, 1-43. http://dx.doi.org/10.2139/ ssrn.3079844.

Mitschell, M. (2019). Do Targeted Economic Development Deals work as Advertised. Mercatus Center at George Mason University. https://neighbourhoodeffects.mercato. org/2013/05/21/do-targeted-economic-development-delas-work-as-advertised.

Organisation for Economic Co-operation and Development (OECD) (2001). https://www. oecd.org/, https://stats.oecd.org/glossary/detail.asp?ID=303\#: :text=Central\%20

and $\% 20$ Eastern $\% 20$ European $\% 20$ Countries\%20(CEECs) $\% 20$ is $\% 20$ an $\% 20$ OECD\%20term,\%3A\%20Estonia\%2C\%20Latvia\%20and\%20Lithuania.

Osario, C., \& Florida, A.P.R. (2017). Business Incentives Are Ineffective and Wasteful, https://www.Citylab.com/life/2017/03/business tax-incentives-waste/518754 (accessed: 7.03.2017).

OurWorldInData.org (2021). Groningen Growth and Development Centre, https:// www.rug.nl/ggdc/productivity/pwt.

Peters, A., \& Fisher, P. (2004). Failures of Economic Incentives. Journal of American Planning Association, 70(1), 27-37. http://dx.doi.org/10.1080/01944360408976336.

Petrin, T. (2018). A Literature Review on the Impact and Effectiveness of Government Support for R/D and Innovation. Working Paper at Faculty of Economics: University of Ljubljana. http://www.isigrowth.eu/2018/02/14/a-literature-review-on-the-impact-and-effectiveness-of-government-support-for-rd-and-innovation.

PEW (2019). What makes an Economic Incentive Effective? https://www.pewtrusts. org/en/research-and-analysis/data-visualizations/2019/what-makes-an-economic-development-incentive-effective. 
Pontryagin, L.L, Boltyanskii, V.G., Gamkrelidze, R.V, \& Mishechenko, E.F. (1962). The Mathematical Theory of Optimal Processes. New York: John Wiley \& Sons. http:// dx.doi.org/10.1002/zamm.19630431023.

Prillaman, S.A., \& Meier, K.J. (2014). Taxes, Incentives, and Economic Growth: Assessing the Impact of Pro-Business Taxes on U.S. State Economies. Journal of Politics, 76(2), 364-379. http://dx.doi.org/10.1017/S0022381613001345.

Radosevic, S. (2017). Upgrading technology in Central and Eastern European economies. IZA World of Labor, 338. http://dx.doi.org/10.15185/izawol.338.

Schwab, K. (2019). The Global Competitiveness Report 2019. Cologny: World Economic Forum.

Schwartz, A. (2018). The Realities of Economic Development Subsidies. Washington: Center for American Progress. https://www.americanprogress.org/issues/economy/ reports/2018/11/01/457771/realities-economic-development-subsidies.

Skorupinska, A., \& Torrent-Sellers, J. (2015). The Role of ICT in the productivity of Central and Eastern European Countries: Cross Country Comparison. Reviste de Economia Mundial, 39, 201-221.

Sprzeuzkouski, A. (1967). A Problem in Optimal Stock Control Management. Journal of Optimization Theory Applications, 1(3), 232-241. http://dx.doi.org/10.1007/ BF00926065.

Tadesse, T., \& Melaku, T. (2019). Analysis of the Relative Impact of Monetary and Fiscal Policies on Economic Growth in Ethiopia using ARDL Approach to Co-Integration: Which Policy is more important? Copernicus Journal of Finance \& Accounting, 8(2), 87-115. http://dx.doi.org/10.12775/CJFA.2019.010.

Taylor, J.G. (1972). Comments on Multiplier Condition for Problems with State Variable Inequality Constraints. IEEE Transactions on Automatic Control, 17(5), 743-744.

TRADING ECONOMICS (2020). Trading Economics, https://tradingeconomics.com/ country-list/interest-rate?continent=europe (accessed 29.07.2020).

World Bank (1999). How Tax Policy and Incentives Affect Foreign Direct Investment: A Review. Policy Research Working Papers. http://dx.doi.org/10.1596/1813-94502509.

Zee, H., Stotsky, J.G., \& Ley, E. (2002). Tax Incentives for Business Investment: A Primer for Policy Makers in Developing Countries. World Development, 30(9), 1497-1516. 